\title{
Gemeentes as begeleiers van kollektiewe rouprosesse
}

\author{
Author: \\ Willem S. Boshoff ${ }^{1,2}$ \\ Affiliations: \\ ${ }^{1}$ Postgraduate student, \\ Department of Practical \\ Theology, University of \\ Pretoria, South Africa \\ ${ }^{2}$ Ducth Reformed Church \\ Hartbeesspruit-Queenswood, \\ Pretoria, South Africa

\section{Correspondence to:} \\ Willem Boshoff \\ Email: \\ willemboshoff@telkomsa.net \\ Postal address: \\ PO Box 11869, Queenswood \\ 0121, South Africa \\ Dates: \\ Received: 08 Mar. 2012 \\ Accepted: 09 July 2012 \\ Published: 07 Nov. 2012 \\ How to cite this article: \\ Boshoff, W.S., 2012, \\ 'Gemeentes as begeleiers \\ van kollektiewe rouprosesse', \\ Verbum et Ecclesia 33(1), Art. \\ \#726, 9 pages. http://dx.doi. \\ org/10.4102/ve.v33i1.726
}

(C) 2012. The Authors. Licensee: AOSIS OpenJournals. This work is licensed under the Creative Commons Attribution License.
Local congregations as facilitators of collective grieving. Since 1990 South Africa has been characterised by far-reaching change in all spheres of society. A recent PhD dissertation completed at the University of Pretoria described the loss members of the Dutch Reformed Church (DRC) experience because of the rapid change. Experiences of loss are common enough to be described as collective experiences of a community. Resulting grief processes are long standing and unresolved. Grieving is the normal human response to loss, but many DRC members (and probably the denomination and the whole Afrikaans community), got stuck because of unresolved grief dynamics. The main contribution of this article is to argue that local communities of faith can serve its members and the community by accepting the task to initiate and guide collective grief processes. Intentional grief is seen as a ministry of hope, resulting in a new and more appropriate identity.

\section{Inleiding}

Suid-Afrika het sedert 1990 grondliggend en omvangryk verander. Die datum van 02 Februarie 1990 kan as 'n waterskeidingsdatum beskou word. Op hierdie dag het die destydse president F.W. de Klerk tydens ' $n$ toespraak in die parlement aangekondig dat die beperkings op die African National Congress (ANC) opgehef word en dat mnr Nelson Mandela uit die tronk vrygelaat sou word. Die bal is met hierdie stap aan die rol gesit vir groot en noodwendige veranderings. Omvattende en uiters komplekse verskuiwings het sedertdien in elke faset van die Suid-Afrikaanse samelewing plaasgevind. Die probleem wat hierdie artikel aanspreek, is dat omvattende en langdurige prosesse van verandering, belewenisse van verlies in die Afrikaanse gemeenskap tot gevolg het. Die Nasionale Party regering van die voorafgaande periode (1948-1994) was immers hoofsaaklik Afrikaans.

Die spontane, menslike reaksie op verlies is om te treur. Dit manifesteer in talle fisiese, sosiale emosionele, kognitiewe en gedragsimptome (vgl. Bowlby 1980; Payne, Horn \& Relf 1999:21-25; Worden 2003:21-36). 'n Onlangse hipotese-genererende studie het ' $n$ in-diepte beskrywing aangebied van die huidige stand van sake ten opsigte van drie verbandhoudende, kontekstuele faktore: verandering in Suid-Afrika; verlies wat Nederduits Gereformeerde (NG) Kerk-lidmate beleef; en treurreaksies as gevolg van verlies. ${ }^{1}$ Die navorsingsvermoede is bevestig dat ervarings van verlies só algemeen en herhalend voorkom dat:

- dit beskou kan word as kollektiewe ervarings van 'n hele gemeenskap

- dit langdurige en onafgehandelde treurprosesse tot gevolg het (Boshoff 2011:376).

Bogenoemde proefskrif se empiriese studie is slegs in gemeentes van die NG Kerk uitgevoer, maar dieselfde prosesse is waarskynlik algemeen in die hele Afrikaanse gemeenskap. Die treurproses bly onafgehandel, omdat mense gedurig wéér verlies beleef en omdat daar geen grootskaalse, daadwerklike poging is om Afrikaners te help rou nie. 'n Treurproses neem baie geestesenergie in beslag: energie wat vir ander, meer produktiewe doeleindes aangewend sou kon word: '... grief becomes a literal black hole devouring the spiritual and relational energy within the Gospel community' (Hamman 2005:28). 'n Verdere navorsingsbevinding is dat die heersende treurproses ' $n$ hindernis vir sinvolle gemeentebou is, omdat dit gemeentes van energie beroof en die aandag na binne fokus (Boshoff 2011:1-11,375-376). Gemeentebou sal dus meer geredelik slaag wanneer gemeentes gehelp word om met hulle rouproses te vorder. Die hipotese aan die einde van die studie lui dan soos volg:

Gemeentebou sal meer geredelik slaag in gemeentes van die NG Kerk se Noordelike Sinode wanneer die kollektiewe treur- en roureaksies oor verliese in Suid-Afrika ná 1990 grootliks afgehandel is en meer geestesenergie beskikbaar is om die uitdagings van optimale, missionêre gemeentewees aan te pak. Praktiese teologie kan 'n bydrae in dié verband lewer deur. (Boshoff 2011)

1.W.S. Boshoff se PhD-proefskrif 'Gemeentebou en die begeleiding van rouprosesse in ' $n$ konteks van omvattende verandering' is in 2011 voltooi onder leiding van prof. Malan Nel, Departement Praktiese Teologie, Teologiese Fakulteit, Universiteit van Pretoria. 
- 'n gemeentebouteorie te ontwikkel waarin die konteksspesifieke nood van lidmate en gemeentes, naamlik die noodsaaklikheid om verliese genoegsaam te betreur en te groei na 'n nuwe identiteit, geïntegreer is,

- intensionele rou, as bediening van hoop, te integreer as 'n normale deel van die gemeente se bediening. (Boshoff 2011:400)

Die hipotese van hierdie artikel is dat Afrikaanse gemeentes in die huidige konteks en tydsgewrig 'n betekenisvolle bydrae aan gemeente en gemeenskap kan lewer deur begeleiers van kollektiewe rouprosesse te word. Die doel is om te fokus op die tweede moontlike bydrae van die praktiese teologie wat in bogenoemde hipotese uitgespel is en weë te ondersoek hoe die begeleiding van rouprosesse gevestig kan word as 'n normale deel van gemeentes se bediening.

\section{'n Gemeenskap gekenmerk deur verlies en treur}

Die kollig val hier op 'n vergete en verwaarloosde, nietasbare element van die Suid-Afrikaanse konteks: die verlies wat Blanke persone in die algemeen en Afrikaners in die besonder beleef in die nadraai van die politieke veranderings van 1994. Hierdie veranderinge het afgespeel teen die agtergrond van die emansipasieproses van die kontinent Afrika uit die koloniale era sedert 1957 en verder teen die agtergrond van groot internasionale veranderinge gedurende dieselfde tydperk (vgl. Van Rensburg 1979; Boshoff 2011:149-154).

Die opmerksame waarnemer is bewus van oorvloedige tekens van treursimptome soos ontkenning, aggressie en neerslagtigheid in die Afrikaanse gemeenskap (vir beskrywings van treursimptome wat algemeen geld, sien Kübler-Ross 1969:34-98; Bowlby 1980:85-111; Parkes 1986: 50-106). Die treursimptome wat tans volop in drie geselekteerde gemeentes van die NG Kerk voorkom, word vervolgens aangestip (sien Boshoff 2011:374). By elke treursimptoom word slegs een respondent se reaksie uit die empiriese studie aangehaal. Die respondente se kodes word weergegee soos in die oorspronklike studie, om hulle privaatheid te beskerm:

- Ontkenning en isolasie: 'Die onttrekking het só geklink: As jy jou onttrek in jou eie huis, dan is daar nog'n gemeenskap daar buite. Daar is nog 'n kerk, want daar moet mos een wees. Daar is nog 'n skool, want daar moet mos 'n skool wees. Daardie ouens kan net nie meer funksioneer nie, want jy onttrek. Maar hulle onttrek, sodat hulle kan glo die goed gaan aan. Hulle wil nie hoor wat gaan aan nie. Hulle wil nie hoor daar is nie geld nie. Hulle wil nie hoor die volgende ou verkoop sy plaas nie. Jy kry die ongelooflike ironie. Kyk, ons gemeenskap het in totaliteit verander. Nou sê die ouens wat in hulle huise gebly het, maar hulle ken nie meer hierdie plek nie. Hulle voel, nee hulle voel nie, hulle IS vreemdelinge in die gemeenskap - die nuwe ene. Want die ou ene, wat hulle geglo het aangegaan, het nie aangegaan nie. En die nuwe een het hulle nie gesien gebeur nie ...' (Respondent D, 53 jaar oud).

- Emosionele pyn: 'Daar is 'n HARTSEER in die mense wat hulle nie uitgepraat kry nie en dit bly half daar. Iewers moet ons kom om deur dit te trek. Maar ek sien, ek sien nog nie daardie groot swaai op nie.' (Respondent Z, 45 jaar oud).

- Vyandigheid/aggressie/woede: 'Ja, maar die feit dat die ouens treur oor ... omdat hulle werkloos raak, of omdat hulle nie werk kan kry nie en dat hulle dit toeskryf as gevolg van politieke verandering, kan 'n mense nie doodpraat nie, dit is inderdaad so. Daardie tipe van ... ek wil amper sê, ek wil amper die woord "treur" vervang met "woede". Woede is in baie ouens teenwoordig. Dit is so. Mens kan dit nie wegpraat nie.' (Respondent V, 74 jaar oud).

- Wanhoop/neerslagtigheid/gees van pessimisme: 'Ek dink die treurproses word meer algemeen waargeneem as 'n gees van negatiwiteit. Oral waar jy kom en met mense praat, is dit negatief. Mense praat nie positiewe goeters nie. Jy praat jou meer in 'n depressie in, meer in 'n groef in' (Respondent 6, 76 jaar oud) (Boshoff 2011:254-371).

Al vier hierdie simptome word met die beginstadiums van 'n treurproses geassosieer. Daar is nog min tekens van die laaste fases van die treurproses. Sommige outeurs dui die laaste fases aan as die aanvaarding van die werklikheid ná die verlies en die herinvestering van geestesenergie in iets of iemand anders as dít wat jy verloor het (Kübler-Ross 1969:99-138). Ander outeurs beskou 'n nuwe identiteit, onafhanklik van die verlore geliefde, nuwe energie en 'n duidelike doel om voor te leef in die omstandighede ná verlies, as aanduidings dat die treurproses afgehandel raak (Parkes 1986:107-123; Hamman 2005:47).

Die dilemma van die NG Kerk ten opsigte van verlies en treur, in die lig van haar geskiedenis met apartheid (vgl. Kinghorn 1986), word soos volg verwoord:

But how do you grieve something that you have confessed as a sin? This paradox cannot be solved, for the body of Christ does not live only theologically, ecumenically, or even ethically, but also emotionally and relationally. The DRCSA as a denomination and most of their congregations remain stuck due to the dynamics of grief. (Hamman 2005:15-16)

Meeste individue en gemeentes haak klaarblyklik by die beginstadiums van die treurproses vas. Daarom is daar nog soveel onsekerheid in Afrikaanse kerke oor identiteit, roeping en unieke bydrae in die 'nuwe Suid-Afrika'.

\section{Treur het 'n impak op gemeentebou}

Die treurprosesse van lidmate het ongetwyfeld ' $n$ impak op die funksionering van gemeentes en daarom kom die vakgebied gemeentebou in spel. Gemeentebou word hier gedefinieer as dié deel van die praktiese teologie wat vra na die wese, roeping en optimale, totale funksionering van die gemeente as teken van die komende Koninkryk van God (Boshoff 2011:190-191). Die huidige gemeenteboudilemma in die NG Kerk is die volgende (dit is waarskynlik soortgelyk in ander Afrikaanse kerke): Die NG Kerk huldig onbeskroomd 'n missionêre teologiese teorie, soos verwoord in die Algemene Sinode van 2002 se beleidstuk Buitelyne van 'n gereformeerde gemeentelike ekklesiologie (vgl. ook Jonker 1977; 
Bosch 1979:22-85; Hendriks 1994:180-191; Nel 2002:54-59, 2006:11-21; Kok \& Niemandt 2009). In teenstelling met die teologiese teorie, leef meeste gemeentes egter vreemd na binne gekeer. Die navorsingsvermoede is dat die konteks van omvattende verandering, waarbinne gemeentes hulle die afgelope 22 en meer jare bevind, een van die faktore is wat die impasse veroorsaak.

Die gemeentebouprobleem is die volgende:

Min NG Kerk-gemeentes slaag tans daarin om die versorgingsdimensie van hulle bediening te balanseer met ' $n$ voldoende missionêre dimensie. Vrae wat na vore kom, is die volgende:

1. Is daar samelewingsfaktore wat gemeentebou-ideale en gemeenteboupogings demp?

2. Is dit akkuraat om te beweer dat daar 'n langdurige, onvoltooide en kollektiewe treurproses in die Afrikaanse gemeenskap aan die gang is wat NG Kerk-lidmate en gemeentes se geestesenergie dreineer?

3. Kan 'n gemeentebouteorie wat die huidige treurproses verreken, ' $n$ bydrae lewer om die probleem op te los? (Boshoff 2011:10)

\section{'n Studie in die 'nuwe' praktiese teologie, gebou op 'n 'nuwe' epistemologie}

Hierdie studie kom teologies tuis in die geselskap van die 'nuwe' praktiese teologie wat sedert die laat sestigerjare in Europa (Firet 1968, 1987; Heitink 1984, 1993; Van der Ven 1993; Dingemans 1996) en die VSA (Browning 1991; Osmer 2008) ontwikkel is en sedert die laat tagtigerjare vinnig veld gewen het in Suid-Afrika (Heyns \& Pieterse 1990; Pieterse 1991, 1993; Nel 1991; Burger 1991, 1995, 1999; Müller 1996; Louw 1999).

Praktiese teologie en ander vakgebiede wat by die sosiale en subjektiewe werklikhede betrokke is, kan nie reken op sekerheid en ewige waarheid nie (vgl. Van Aarde 2004: 1107-1113). Ons lewe in 'n tyd van groeiende kognitiewe pluralisme (Gregersen \& Van Huyssteen 1998:3). Dit impliseer egter nie epistemologiese oorgawe aan radikale relativisme nie. J. Wentzel van Huyssteen en andere het sedert die negentigerjare die 'postfoundational' benadering in die teologie ontwikkel (Gregersen \& Van Huyssteen 1998:7-8, 13-50; Van Huyssteen 2006:xiv). Dit soek 'n middeweg tussen die objektiewe ideaal van die modernisme na Newton en die radikale relativisme van sekere eksponente van die postmodernisme na Einstein:

Over against the objectivism of foundationalism and the extreme relativism of most forms of nonfoundationalism, a postfoundationalist notion of rationality helps us to acknowledge contextuality, the shaping role of tradition and of interpreted experience, while at the same time enabling us to reach out beyond our own groups, communities and cultures, in plausible forms of intersubjective, cross-contextual, and cross-disciplinary conversations. (Van Huyssteen 2006:10)

Objektiewe waarheid is nie haalbaar nie - dit is wensdenke (Van Aarde 2004:1107). Dit is ook nie die ideaal van hierdie studie nie. Wat wel deeglik in die visier is, is kontekstueel verankerde, intersubjektiewe geldigheids-, juistheids- en waaragtigheidsaansprake wat met argumente bevestig of weerlê kan word (vgl. Pieterse 1991:42-43).

\section{Konteks en empiriese studie is belangrik vir die praktiese teologie}

Insig in die konteks is krities belangrik vir die Christelike geloof en vir elkeen wat nadink oor geloof. Hedendaagse praktiese teoloë het konsensus daaroor (Pieterse 2002; Müller 2005; Nel 2006; Osmer 2008). Gelowige en konteks; gemeente en gemeenskap hoort by mekaar. Die soort praktiese teologie wat in hierdie artikel onderskryf word, is 'n teologie van betrokkenheid: '... de empirisch-georiënteerde theologische theorie van de bemiddeling van het christelijk geloof in de praxis van de moderne samelewing' (Heitink 1993:18).

Die geboorteplek van teologie is dus nie net die Bybel en die geloofstradisie nie, maar ook die konteks waarin gelowiges geroep is om hoop te bring en 'n verskil te maak (vgl. Gregersen \& Van Huyssteen 1998:4-5). Die bekende Duitse dogmatikus Jürgen Moltmann (2000) skryf as ou man die volgende oor die herkoms van sy teologie:

My experiences of death at the end of the war, the depression into which the guilt of my people plunged me, and the inner perils of utter resignation behind barbed wire: these were the places where my theology was born. (p. 4)

Goeie teologie word nie in 'n vakuum gebore of bedryf nie, maar altyd in 'n bepaalde konteks. Wanneer die omgewing so vinnig en so omvattend verander soos Suid-Afrika die afgelope twee dekades, is dit nie vanselfsprekend vir 'n gemeente om kontekstueel akkuraat te wees nie. Hierdie artikel wil 'n bydrae lewer tot die verstaan van Afrikaanse kerke se konteks in 2012.

\section{Die konteks geniet ' $n$ bepaalde voorrang in die prakties-teologiese proses}

Die teorie-praxis spanningseenheid het sedert 1990 in Afrikaans bekend geword 'as die belangrikste stuk gereedskap van die praktiese teologie' (Heyns \& Pieterse 1990:35). Daar is konsensus oor die belang van beide die teologiese teorie en die konteks vir die groei van teologie (Heitink 1993; Pieterse 1993; Browning 2007; Osmer 2008), maar ek meen die konteks geniet ' $n$ bepaalde voorrang: Die prakties-teologiese proses begin gewoonlik by vrae wat uit die praktyk opduik, of by onbehae met dinge in die geloofspraktyk wat nie reg is nie. Die ondersoekproses begin met 'n praktiese belang by die konteks, vanwaar dit beweeg na die teologiese teorie, om weer by die konteks te eindig (Browning 2007:4). Osmer (2008:4) meen ook dit is die praktiese teologie se eerste taak om die relevante konteks te leer ken en te beskryf. Diepgaande begrip van die konteks is belangrik vir gemeentes wat optimaal as kerk van Jesus Christus wil funksioneer.

In die praktiese teologie is empiriese data is nie net nuttig nie, maar noodsaaklik vir die ontwikkeling van die vakgebied (Heyns \& Pieterse 1990:75-80; Van der Ven 1993:1-8; Browning 
2007:4, Osmer 2008:31-73). Betekenisvolle empiriese werk kan die teologie help om sy beeld van wêreldvreemdheid af te skud (vgl. Burger 1994:84; Nel 2003:18-20) en die kloof tussen teologiese teorie en mense se leefwêreld te oorbrug. Hierdie artikel gaan aanhaal uit die empiriese ondersoek van Boshoff (2011:252-376). Die uitgangspunt daarvan was die ervaringswêreld van drie geselekteerde NG Kerk-gemeentes se lidmate in 2010 en die aktuele situasies waarin hulle hul geloof in die samelewing uitleef (sien Dingemans 1996:35; Osmer \& Schweizer 2003:5).

\section{Metodologiese oorwegings}

Die wêreld van die moderne wetenskapsbeoefening en kennisverwerwing is divers en daar is verskeie onderliggende filosofieë. 'There are - quite simply - different ways of knowing' (Moses \& Knutsen 2007:1). Die basiese metodologiese vraag (wat volg op die ontologiese en epistemologiese vrae), is: 'Hoe word kennis verwerf?' (vgl. Moses \& Knutsen 2007:5).

Hierdieondersoek kies metodologies vir'n konstruktivistiese navorsingsfilosofie. Respondente wat aan die ondersoek deelgeneem het, se waarnemings is nie objektief nie. Hulle gesigspunte is waaragtig en wetenskaplik bruikbaar, maar telkens geïnterpreteerde weergawes van die werklikheid (Pieterse 2002:83). Metodologies is daar ruimte geskep vir unieke stemme wat elk praat oor betekenis wat hulle toeken aan hulle wêreld, vanuit hul eie persepsies van die werklikheid: ' ... constructivists recognize that people may look at the same thing and perceive it differently' (Moses \& Knutsen 2007:11).

\section{Waarde van die kwalitatiewe styl van navorsing}

Daar is konsensus tussen leidende praktiese teoloë, dat beide die kwantitatiewe en die kwalitatiewe style van empiriese navorsing bruikbaar is en dat die keuse van navorsingstrategie afhang van die navorsingsprobleem en die vrae wat die navorser wil beantwoord (Claessens \& Van Tillo 1990:44; Heitink 1993:219-223; Pieterse 1993:177-188; Dreyer 1998; Kritzinger 2000:16).

In Boshoff (2011:95-116) het ek gekies om van kwalitatiewe navorsing gebruik te maak. In die algemeen word kwalitatiewe navorsing met 'n onderliggende interpretatiewe filosofie (Mason 1996:3; Wester \& Peters 2004:21) geassosieer. Sosiale en menslike kompleksiteite word in ryk detail ondersoek en vertolk. Die navorsingstyl is holisties van aard: alle faktore wat vir die respondente belangrik is, is ter sake: 'Qualitative research aims to produce rounded understandings on the basis of rich, contextual and detailed data' (Mason 1996:4). Die oogmerk van die empiriese studie waaruit hierdie artikel put was om baie data, gedetailleerde data en moontlik ook teenstrydige data in te samel, wat reg kan laat geskied aan individue en gemeentes se persepsies, belewenisse en response in die nuwe Suid-Afrika (Boshoff 2011:252-376).

Vir kwalitatiewe navorsing maak die grootte van die navorsingsveld en die getalle mense in die navorsingsveld nie saak nie: die fokus is op die spesifieke hoedanighede, die aard en gesteldheid, die unieke eienskappe van die ondersoekveld (vgl. Wester \& Peters 2004:11). Die bedoeling is om 'n klein veld van ondersoek in diepte te verstaan. In die geval van die onderhawige gemeenteboustudie gaan dit om stemme van 'n klein aantal respondente (slegs 31) uit slegs drie gemeentes van die NG Kerk se Noordelike Sinode. Die spesifieke kontekste waar mense leef, word besonder ernstig opgeneem (Mason 1996:4). Dit is aantreklik vir 'n ondersoek soos hierdie, omdat die verandering in die Suid-Afrikaanse konteks wat aanleiding gegee het tot die studie, verskil van plek tot plek. Toe drie gemeentes vir gevallestudies geselekteer is, is doelbewus gepoog om verskeidenheid van gemeentelike kontekste in te sluit (Boshoff 2011:125-127).

\section{Belangrikste resultate van empiriese studie}

Vervolgens word 'n bondige beskrywing aangebied van die huidige stand van sake ten opsigte van die drie verbandhoudende, kontekstuele faktore: verandering in Suid-Afrika, verlies wat NG Kerk-lidmate beleef en treurreaksies as gevolg van verlies.

Volop woordelikse aanhalings word gegee uit halfgestruktureerde onderhoude en insette van fokusgroepe (vgl. Wester \& Peters 2004:37, 61-66; Baarda et al. 1998:132-135), om die prakties-teologiese proses, met so min as moontlik filters, naby aan die respondente se belewenis van hulle konteks te bring. Taalkundige en sinskonstruksiefoute is nie reggemaak nie. Spreektaal is soms 'morsig', maar dit bring die leser so naby as moontlik aan die oorspronklike data (Putcha \& Potter 2004:2).

\section{Die Afrikaanse gemeenskap het die politieke mag verloor}

Byna al die respondente het oor die voor die hand liggende politieke verandering gepraat. Ek haal slegs een aan:

'Die grootste verandering was die magsverlies van die Afrikaanse gemeenskap, vanuit die gemeenskap se oogpunt. Die indruk waarmee die Afrikaanse gemeenskap gewerk het (dink ek), is dat hy mag gaan deel, dat hy selfbeskikking gaan hê as 'n minderheidsgroep en dat hy homself met ' $n$ grondwet verskans het ... Nou: dit het hulle verloor. Die besef van, sê maar die swart meerderheid, wat hom nie laat lei deur die grondwet nie en wat minderheidsbelange nie ag nie, kom in effek neer op 'n totale magsverlies'. (Respondent D, 53 jaar oud)

\section{Die Nederduits Gereformeerde Kerk het waardering, aansien en erkenning vir haar bydrae in die land verloor}

\footnotetext{
'Die idee was vroeër, in die tagtigs, die NG Kerk doen die ding in die land. Hy het die mag in die hande. Invloedryk. 'n Groot kerk. Dit is nie meer so vanselfsprekend nie ... Dit was 'n traumatiese gebeure in Suid-Afrika en dit het die samelewing geraak: dit het ALMAL geraak. Inderdaad 'n nuwe Suid-Afrika ... Waar jy golwe kry na mekaar, het dubbele golwe, gesamentlike golwe die land getref. Die NG Kerk is in die proses "skoon geboul".' (Respondent $\mathrm{Y}, 50$ jaar oud)
} 
'Die NG Kerk was absoluut dominant gewees in dorp M ... daar was 'n tyd toe die NG Kerk - dit was so half 'n staatskerk gewees en as jy aan die NG Kerk behoort het, dan was jy deel van 'n struktuur wat jou nogal kon in staat stel om dinge gedoen te kry. Dit het verval.' (Respondent B, 43 jaar oud)

\section{Geloofwaardigheidskrisis en morele verval}

Dit blyk dat die gesag van leiersfigure en daarmee saam moraliteit in die algemeen in gedrang kom:

'Die morele samestelling, die morele waardes het baie verander van toe tot nou. As jy vat toe was daar sterk morele kodes onder mense gewees, voor die tyd. Daar het 'n skielike verwatering ingekom ... Mense het meer wette begin oortree, padreëls, ensovoorts, ensovoorts. Daar is heeltemal 'n verwatering, want as dié ou dit kan doen, kan ek dit ook doen. Ons hele samelewing het op 'n manier verval ...' (Respondent C, 64 jaar oud)

\section{Transformasie, regstellende aksie, werk- en funksieverlies}

Respondent 3 merk op dat daar in die jare voor $1990 \mathrm{~min}$ werkloosheid in Blanke geledere voorgekom het. Dit het verander as gevolg van transformasie en die regering se beleid van Swart ekonomiese bemagtiging. Wanneer mense, wat vroeër werksekuriteit beleef het, hulle werk verloor, veroorsaak dit 'n krisis in die huis. Blanke persone wat nie skaars vaardighede het nie, sukkel om werk te kry. Die volgende, voorheen onbekende, patroon herhaal hom oor en oor in party Blanke persone se lewens: "'Meneer, ek het werk nodig." "Nee, daar is nie vir jou werk nie." Dit veroorsaak 'n vreeslike treurigheid, 'n hartseer in ons land' (Respondent 3, 51 jaar oud).

\section{Respondent $C$ praat vanuit sy persoonlike ervaring:}

\begin{abstract}
'As ek vat voor 1990, as ek nou myself vat, ek voel amper soos daardie outjie van "Boetman is die bliksem in". Jy het jou bekwaam. As ek myself as ' $n$ voorbeeld kan vat, ek het myself bekwaam met 'n redelik sterk opleiding, 'n paar grade, ensovoorts. Toe skielik kom ek agter, maar ek kan nie werk kry nie. Toe het regstellende aksie ingetree en ek het woedend geword. Ek het gedink ek gaan vir my vrou en kinders kan sorg die heel tyd. Ek moes toe terugval op 'n entrepreneurseienskap en dinge op ' $n$ ander manier begin doen. So, dit was 'n groot probleem vir my om te kan aanvaar ...' (Respondent C, 64 jaar oud)
\end{abstract}

'n Ander respondent, wat nóú met 'n 'nuwe' staatsdepartement saamgewerk het, het vroeër afgetree as wat sy voorsien het, as gevolg van identiteits- en funksieverlies by die werk en omdat haar gesondheid begin ly het onder die chroniese spanning by die werk:

'Maar sonder identiteit is dit moeilik om die pad te vind, hoor! 'n Mens gooi ook nie identiteit oor jou skouer en dan ewe skielik weet jy weer waar is jy op pad heen nie. So, ek dink dit het baie bygedra daartoe dat ek op die end van die dag vroeër afgetree het as wat ek wou afgetree het.' (Respondent $X, 55$ jaar oud)

Sy beoordeel haar vervroegde aftrede negatief: 'Dis soos ek gevoel het. Ek het daar geabdikeer.' Ses jaar of meer van haar professionele beroepsloopbaan as gegradueerde, ervare en gemotiveerde persoon in 'n senior pos, het verlore gegaan:
'Uhm, ja, ek wil eerlik sê 'n deel van die vervroegde pensioen is die veranderde bestel in Suid-Afrika. Ek is seker ek sou nog ' $n$ hele paar jare baie vrugbaar kon besig wees.' (Respondent X, 55 jaar oud)

\section{Finansiële verliese}

Dit het geblyk daar is baie meer werksverlies, werkloosheid en armoede onder Blanke persone was as in die vorige bedeling (Respondent V, Respondent $\mathrm{W}$ en Respondent $\mathrm{Z}$ ). Werksverliese het 'n negatiewe invloed op die betrokkenes se sosiale status en lewenstandaard. Die groot getal Blanke plakkerskampe is 'n nuwe verskynsel in Suid-Afrika (Respondent V). 'n Nuwe geslag Armblankes het ewe skielik begin ontwikkel (Respondent Z).

\section{Emigrasie}

Al die respondente rapporteer verlies as gevolg van emigrasie:

‘Ja, ja. Twee van my kleinneefs, een van hulle was betrokke by die boerdery hier, hy sit op die oomblik in Nieu-Seeland. En dis mense wat ons regtigwaar in hierdie land sou baie goed kon gebruik. Hulle was betrokke by die kerk, hulle was ... Ons het hulle verloor. En hulle se kinders is nou Nieu-Seelanders. Die kleintjie word 'n All Black (lag). Ja, sy held is nou Richie McCaw en as hulle die dag weer terugkom in Suid-Afrika, gaan dit seker 'n probleem afgee ... (lag).' (Respondent A, 78 jaar oud)

'Jy skype, maar jou hart trek met 'n punt ...' (Respondent $X$, 55 jaar oud).

Die pyn en verlies wat met emigrasie gepaard gaan, raak nie ligter met die verloop van tyd nie:

'Dis absoluut 'n moeilike ding, maar ek dink dit laat treur nogal vasbyt by die mense ... dit is baie moeilik (ek sien dit by hoevéél mense) as daar besoeke heen en weer plaasvind, want dis elke keer die afskeid. Dis elke keer, en vernaam as dit ouer mense is, dan ... die kinders dink 'miskien sien ek hulle nie weer nie', die ouers dink miskien ... Dis ' $n$ baie ingewikkelde situasie. Dis nie so eenvoudig van 'oh, ons gaan na die paradys toe' nie, of 'ons oorleef maar net'. Daar is 'n ander tipe treur wat ook bykom, jy weet, daardie verlies van jou familielede wat jy nou moet hanteer en dit bou op die probleme wat hier reeds is ... Dis MOEILIK, dis 'n baie moeilike en komplekse situasie daardie. Ek dink dit sit net nog druk op die gemeenskap soos wat dit is.' (Respondent $Z$, 45 jaar oud)

\section{Misdaad, verlies van persoonlike gevoel van veiligheid}

'Mense voel nie meer veilig in ons land nie. Dis ' $n$ GROOT ding wat almal oor praat en op almal se lippe is. Ek werk met kinders wat nagmerries kry - hulle was nog nooit self in 'n situasie waar iets met hulle gebeur het nie, maar van hoor by hulle maatjies en by ouers en by almal wat aangaan, is hulle so bang om te gaan slaap in die nag. Hulle is nie veilig ... hulle voel nie veilig nie'. (Respondent T, 32 jaar oud)

'My buurman is in daardie tyd ook vermoor hier. Skokkende voorvalle het plaasgevind.' (Respondent A, 78 jaar oud)

'As ek oor die samelewing moet sê, dan voel ek verontwaardig daaroor. Ek voel ontevrede daaroor, want ek is ontneem van baie dinge. Ek is beroof van my vryheid van beweging, van my 
gemaklikheid waarmee ek mense kon vertrou of dinge kon doen. As jy vandag in 'n hysbak wil inklim, kyk jy eers wie is in die hysbak voor jy inklim. As my dogter vir my binne 'n ommuurde erf sê sy gaan daar in die hoek by die honde sit, sal ek elke keer roep en sê: "is jy oraait?" ' (Respondent E, 60 jaar oud)

\section{Veiligheidsmagte: held of skurk?}

Die posisie van mense wat in die ou bedeling aan die veiligheidsmagte verbonde was, blyk besonder problematies te wees. Die 'goeie soldaat' van die ou bedeling is:

'... in 'n sin, aggressief-teleurgesteld, né? Want hy het sy hele lewe daarvoor gegee. Nou kom almal en vertel vir hom: "jy was eintlik sleg. Hoe kon jy daardie ouens vervolg het?" ... Ek dink daar was baie mense, baie mans wat voel: "Ek was die held, nou is ek ewe skielik niks"'. (Respondent Z, 45 jaar oud)

Dieselfde loopbaan waarop hulle eens trots was, is nou die bron van vervolging, neerhalende openbare aanmerkings, skuldgevoelens, min selfvertroue en 'n lae selfbeeld. Baie van daardie lede is steeds ontnugter, woedend of depressief. Baie ly aan algemene rigtingloosheid en onvermoë om sin te maak van hulle lewens. Dit is nie regverdig teenoor die individu nie, maar dit is hulle stryd in die nuwe bedeling (Respondent Z, 45 jaar oud).

Nog 'n respondent reageer soos volg:

'My hart gaan so uit, want ek sien die geveg in sy binneste. Hulle het so ... hy was ' $n$ recce en hulle het verskriklike ervarings gehad - ek dink nie ons het meer 'n begrip van watse ervarings hulle gehad het nie. Menige kere (sy hand is ook afgeskiet in een of ander skermutseling) het hulle nagte en nagte gelê binne in die veld en nie geweet of hulle die volgende dag sien nie. Nou is hulle hier terug in die samelewing. Daar is nêrens plek waar hulle kan praat daaroor nie.' (Respondent $X, 55$ jaar oud)

\section{Ouer mense kry swaarder}

Die nuwe politieke bedeling het baie ouer mense in brooden-botter kwessies onkant gevang. Vir meeste bejaardes is dit te laat om finansieel voorsiening te maak vir iets beter:

'Maar as mens gaan kyk na jou ouer garde mense, my ma-hulle het toe hulle grootgeword het, was die mediese diens wat hulle by die hospitaal gekry het, voldoende. Hulle het van die beste diens gekry, van die beste dokters was daar ... So, hulle het nie voorsiening gemaak vir mediese fondse nie, die oumense. Dít wat die staat daargestel het, was meer as genoeg. En baie het nie vir pensioen voorsiening gemaak nie. En eensklaps het hierdie dinge platgeval. Die oumense kry swaar. ' (Respondent 1, 48 jaar oud)

Werkende mense behoort voorsiening te maak daarvoor, maar vir bejaardes is dit te laat: 'Op hulle ouderdom kon hulle nie weer gaan werk nie' (Respondent 1, 48 jaar oud).

\section{Mans pas moeiliker aan}

Daar is ' $n$ opvatting dat daar ook ' $n$ verskil is tussen die twee geslagte se hantering van die veranderings: dat vrouens meer aanpasbaar en meer pragmaties is, terwyl mans meer rigied is:

'Die ou omies kry swaar, want hulle werk met mag en geweld. Ons tannies? Hulle het ... van die begin af het hulle dit die beste gevat ... Hulle "handle" die ding. Mans? Nee, jig, my maat, hulle vat nog 'n "knock" ...' (Respondent 5, 58 jaar oud)

\section{Mense verloor moed en hoop}

Hierdie is 'n punt wat stem tot ernstige kommer:

'Kyk, wat hulle ook verloor het, wat die gemeenskap ook verloor het, is die selfrespek van ' $n$ idealistiese gemeenskap. Want hulle sit met vervalle paaie, met vervalle strukture. Die omgewing se agteruitgang skep 'n minderwaardigheid van - daar is nie meer 'n idealisme wat almal nastrewe nie ... ' (Respondent D, 53 jaar oud)

Respondent C (64 jaar oud) eggo dieselfde sentiment: 'As mens uitsigloos voel, of hoop-loos, ek wil die woord HOOPLOOS stres, jy het hoop-loos gevoel en sterker ankers gesoek in die lewe.'

\section{Verlies van lewensvreugde}

Respondent C (64 jaar oud): "n Groot deel van my lewensvreugde is my ontneem deur die tipe van samelewing waarin ons op hierdie huidige oomblik ons bevind.'

\section{Prakties-teologiese teorie in diens van gemeentes in 'n konteks van omvattende verandering}

Die konteks wat gekenmerk word deur verandering, verlies en 'n kollektiewe, langdurige en onvoltooide treurproses, word in hierdie studie tot onderwerp vir teologiese besinning gemaak. Daar is dinge wat die Kerk kan doen om aktief leiding te gee in 'n konteks van omvattende verandering. Hoofsaak is dat gemeentes die taak kan aanvaar om begeleiers van kollektiewe rouprosesse te word.

\section{Onderskei rou van treur}

Om te treur, is die universele, normale, spontane menslike reaksie op verlies. Dit is om bedroef te wees, verdriet te hê (Odendal \& Gouws 2009:1200) en het emosionele, geestelike, fisiese en verhoudingsdimensies. Om te treur is 'n kragtige en on-vrywillige reaksie. Rou word onderskei van treur. 'Rou' word hier in 'n baie spesifieke sin gebruik as 'n doelbewuste en begeleide proses. Worden (2003:10-18) het die term 'treurtake' ('tasks of mourning') gemunt. Die implikasie is dat die treurproses beïnvloed kan word. Intervensie is moontlik. Waar treur spontaan is, is rou in onderskeid daarvan intensioneel. Dit is die doelbewuste proses om afskeid te neem van dít wat die persoon of groep verloor het: materiële dinge, die bekende, verhoudings, drome, hoop, identiteit, funksie of rol. Rou is die harde werk om doelbewus deur al die treurdimensies te leef, om realisties met verlies en verandering saam te leef. Rou is, anders as treur, 'n gedrewe en hoopvolle proses wat afstuur op 'n nuwe identiteit en lewensruimte (Hamman 2005:18). Die hoopvolle element hiervan is dat individue en gemeentes kan leer om produktief te rou en sodoende ' $n$ nuwe identiteit in nuwe omstandighede te vind. Die begeleiding van rou is dus per definisie ' $n$ bediening van hoop. 'Grieving can bring hope as grief can bring despair' (Hamman 2005:28). Om te moet rou 
is daarom nie vir 'n gemeente slegte nuus nie. Paradoksaal is dit goeie nuus. 'Grieving is the gospel in gospel communities' (Hamman 2005:29).

Die hoofargument van hierdie artikel is dat die begeleiding van rouprosesse in die huidige omstandighede en tydsgewrig, 'n normale deel van Afrikaanse gemeentes se bediening behoort te wees. Die vraag is egter hoe 'n gemeentelike bediening wat rouprosesse begelei kan lyk? Ten slotte word sewe moontlikhede bespreek.

\section{Leiers wat persoonlik rou}

Leiers se persoonlike rou is die skarnier waarop die deur van gemeentelike rou oop- of toegaan (Boshoff 2011:230-236). 'If grief is the news of the moment, ministry implies significant grief work for you as a leader of a Gospel community' (Hamman 2005:35).

Om te rou, is paradoksaal deel van ' $n$ individu en 'n gemeente se groeiproses. Strategies begin die gemeentes se groeiproses by gemeenteleiers wat rou en dan mettertyd die gemeente by die helende proses betrek. Leiers se rou oor hulle persoonlike verliese, asook pynlike ervarings in die bediening, is noodsaaklik vir hulle persoonlike groei en 'n voorvereiste vir die gemeente se groei:

Pastors today are undersheperds of Jesus the Christ. Our task as pastors is to be, as He was, a person of sorrows acquainted with grief. This role defines our ministry to those suffering from grief and separation. To say that we are persons of sorrows infers that we ourselves have suffered losses and separations. Accordingly, we have been obliged to explore our own experiences with grief and separation. (Oates 1997:19)

Leiers se rou help hulle groei en roep op 'n spontane manier die gemeente se rou (en groei) na vore:

When you grieve the disappointments and disillusionments you experience in ministry, you create space for yourself to continue to grow in ministry. Such space in turn makes growth for your congregation possible. (Hamman 2005:29)

\section{Herwaardering van die Bybelse klaaglied}

Die genre van die klaaglied was nie die afgelope dekades gewild nie (Hamman 2005:110). Dit lyk egter of daar heel onlangs 'n wending gekom het en dat daar nuwe waardering is vir die klaaglied (Lee \& Mandolfo 2008:ix). Gemeentes in 'n konteks van verandering, verlies en trauma het die Bybelse oorlewingsliteratuur, protesliteratuur en klaagliedere nodig, want dit stimuleer rou-aktiwiteit (Linafelt 2008:62). 'n Opvolg-artikel word beoog wat die nut van die klaaglied in kollektiewe rouprosesse ondersoek.

\section{Rou in gemeentelike pastoraat}

In gemeentelike pastoraat skep leiers wat betrokke geraak het by ' $n$ persoonlike rouproses die atmosfeer deur te begin gesels oor verlies en fyn te luister na mense se treurreaksies:

If persons can put into words the nameless feelings that overwhelm, they become wiser in their prayers and are beter equipped to turn their tears as unutterable sorrow into meaningful words. (Oates 1997:20)

Die pastor gee nie antwoorde nie, maar skep geleenthede dat lidmate vir hulleself rekenskap kan gee van wat met hulle gebeur het. Terwyl lidmate hul eie verhale van verlies en die verhale van die gemeente se verliese vertel en beoordeel, begin die rouproses in beweging kom. Om te rou, is om pyn en verlies aktief te onthou en te vertolk (Hamman 2005: $74-76,81)$. Sulke aktiewe onthou kan effektief en persoonlik in 'n goeie pastorale gesprek plaasvind. Vir almal wat betrokke raak by sulke gesprekke, is dit onmoontlik om verder in ontkenning te lewe, want die wêreld van verlies kry kontoere soos die stories wat dikwels vertel word én die stories wat nooit gehoor word nie 'n gemeenskaplike sosiale werklikheid skep (vgl. Müller 1996:32-34, 105).

Die ideaal is dat die hele gemeente mettertyd oor en weer by sulke betekenisvolle gesprekke betrokke sal raak. Lidmate, en mettertyd 'n gemeente, kry sodoende die geleentheid om hulle pyn, teleurstelling, aggressie, ontnugtering en ander negatiewe emosies in 'n veilige omgewing te verwoord.

Die volgende groepe mense wat deur die respondente in die empiriese studie geïdentifiseer is as mense wat besonder swaar kry omdat hulle besonder baie verloor het in SuidAfrika ná 1990, kan uitgesonder word in gemeentelike pastoraat:

- mans, veral in die ouer ouderdomsgroep,

- lede van die vorige bedeling se veiligheidsmagte (Boshoff 2011:387-391).

Die hele proses speel af in die atmosfeer waar almal, in die lig van die Evangelie en in verbondenheid met die gemeente van Christus, saam soek na die pad waarop die Gees van God hulle wil uitlei (Heitink 1984:75, 284-289).

\section{Huisbesoek herleef?}

Die rol wat gemeentelike pastoraat in die rouproses van 'n gemeente kan speel, bring huisbesoek (wat in sommige kringe as 'n uitgediende praktyk beskou word) terug na die gemeentebougesprek, maar met 'n nuwe motivering. Pastorale gesprekke wat rou fasiliteer, vind meer geredelik plaas waar daar reeds 'n vertrouensverhouding bestaan (Respondent 6). Heelparty respondente het opgemerk dat die vertrouensverhouding wat tradisioneel tussen lidmate en hulle predikant bestaan het, die afgelope tyd vervlak het. Lidmate het nie die vrymoedigheid om met die leraar oor hulle kwellings en stryd te praat nie, want hy is vir hulle onbekend. Huisbesoek as sodanig fasiliteer nie rou nie, maar dit bevorder vertrouensverhoudings en skep geleenthede vir sinvolle pastorale gesprekke.

\section{Eredienste}

'n Vyfde wyse waarop 'n gemeente die swaar werk van rou kan aanpak, is in haar eredienste (vgl. Louw 1985:33-34; Hamman 2005:108). Die erediens is waarskynlik die enigste openbare byeenkoms waar mense gesamentlik hul verliese kan hanteer. Gelowiges doen dit deur die pyn oor 'n vergange 
era voor die Here te lê. Die verskillende elemente van die liturgie nooi die gemeente uit tot afhanklikheid en deelname. Liturge sal wys wees om, oor 'n onderwerp so kontensieus soos hierdie, saam met ' $n$ eredienswerkgroep aan rouliturgieë te werk. 'n Opvolg-artikel sal die moontlikhede wat 'n rouliturgie in die huidige konteks bied, verder ontgin.

\section{Vryheidsdag}

Een van die nuwe openbare vakansiedae in Suid-Afrika is Vryheidsdag op 27 April. Dit herdenk die eerste algemene verkiesing in 1994 waaraan alle burgers, ongeag velkleur en ras, deelgeneem het. As sodanig is dit 'n dag vir die herdenking van die geboorte van die nuwe Suid-Afrika. Dit is nie nodig om ' $n$ navorsingsprojek te loods om agter te kom dat daardie dag hoofsaaklik deur Afrikaanse gemeentes geïgnoreer word nie. Lidmate geniet gewoonlik die vakansiedag, maar het geen erg aan die vieringe van die dag nie.

Die Sondag naaste aan 27 April kan in gemeentes gebruik word om bestekopname te maak van hulle afskeid van die ou Suid-Afrika en hulle aanpassing in die nuwe SuidAfrika. Die minimum effek van so 'n gebruik kan wees om die ontkenning, wat daar nog in sekere kringe heers in verband met die nuwe era wat in 1994 vir die land en die kontinent aangebreek het, te deurbreek. Die maksimum waarna gemeentes kan streef, is om in 'n nuwe identiteit in te groei en met die volle krag van roepingsbewuste Christene betrokke te raak by die land en kontinent waar die Here hulle geplaas het. Om iets te maak van 27 April, sal moed verg van gemeenteleiers.

\section{Nasionale konferensie 27 April 2014}

Vir dieselfde rede dat dit wys sal wees vir gemeentes om jaarliks ' $n$ vaste datum te hê om te besin oor haar bydrae in die plaaslike konteks, sal dit wys wees vir Afrikaanse kerke om 20 jaar ná 27 April 1994 'n nasionale konferensie te hou om te besin oor identiteit, konteks en roeping. Die tema vir so 'n konferensie kan iets soos die volgende wees: 'Die kerk na 20 jaar in die nuwe Suid-Afrika' of 'Afrikaanse kerke vir Afrika' of 'Identiteit en roeping in 'n veranderende konteks'.

\section{Gevolgtrekking}

Gesonde gemeentes is gedurig (formeel of minder formeel) besig om die konteks waarbinne hulle funksioneer, te probeer verstaan. Situasie- en omgewingsdiagnose is deel van 'n wyse gemeente se strategiese beplanning (vgl. Nel 1994:151-168). Alle gegewens wat nodig is om die optimale funksionering van die gemeente in konteks te evalueer, moet versamel word. Sommige daarvan is 'harde' data soos getalle en geboue; demografiese, politieke en ekonomiese faktore. Maar ander gegewens - wat nie minder belangrik is vir die gemeente se funksionering nie - is 'sagte' data soos die kollektiewe belewenisse van verlies en 'n onafgehandelde, voortslepende treurproses. Die impak van verandering en verlies op 'n betrokke gemeenskap, behoort in elke plaaslike gemeente nagevors te word. Deel van gemeentes se eie ondersoeke na hulle konteks kan wees om treursimptome wat volop in die gemeente en gemeenskap voorkom, te identifiseer. Sodoende kan die gemeente peil hoe ver die treurproses in die plaaslike konteks gevorder het. Sulke inligting kan die gemeente ook aanduidings gee hoe om helpend en dienend daarby betrokke te raak.

Gemeentes kan hulle lidmate, sowel as die gemeenskappe waarin hulle betrokke is, help groei deur intensionele rou, as 'n bediening van hoop, as 'n normale deel van die gemeente se bediening te integreer.

\section{Erkenning \\ Mededingende belange}

Die outeur verklaar dat hy geen finansiële of persoonlike verbintenis het met enige party wat hom nadelig kon beïnvloed in die skryf van hierdie artikel.

\section{Literatuurverwysings}

Algemene Sinode van die Nederduitse Gereformeerde Kerk, 2002, Buitelyne van 'n gereformeerde gemeentelike ekklesiologie, Agenda (Bylae A.8.1).

Baarda, D.B., De Goede, M.P.M. \& Teunissen, J., 1998, Kwalitatief onderzoek: praktische handleiding voor het opzetten en uitvoeren van kwalitatief onderzoek, 1ste druk, Stenfert Kroese, Houten.

Bosch, D.J., 1979, Heil vir die wêreld: Die Christelike sending in teologiese perspektief, NG Kerkboekhandel, Pretoria.

Boshoff, W.S., 2011, 'Gemeentebou en die begeleiding van rouprosesse in 'n konteks van omvattende verandering' PhD-proefskrif, Departement Praktiese Teologie, Universiteit van Pretoria, Pretoria.

Bowlby, J., 1980, Loss, sadness, depression, Basic Books, New York.

Browning, D.S., [1991] 1996, A fundamental practical theology, Augsburg Fortress, Minneapolis.

Browning, D.S., 2007, Equality and the family, Eerdmans, Grand Rapids.

Burger, CW., 1991, Die dinamika van 'n Christelike geloofsgemeenskap: Nuut gedink oor gemeentes, Lux Verbi.BM, Kaapstad.

Burger, C.W., 1994, 'Die agogiese moment in die prediking in 'n situasie van verandering', Praktiese Teologie in Suid-Afrika 9(1), 83-92.

Burger, C.W., 1995, Gemeentes in transito (Vernuwingsgeleenthede in 'n oorgangstyd), Lux Verbi.BM, Kaapstad.

Burger, C.W., 1999, Gemeentes in die kragveld van die Gees. Oor die unieke identiteit, taak en bediening van die kerk van Christus, Buvton, in samewerking met Lux Verbi.BM, Bloemfontein.

Claessens, W. \& Van Tillo, G. (eindred.), 1990, Van beneden naar boven. Een nieuwe richting in de praktische theologie, Kok, Kampen.

Dingemans, G.D.J., 1996a, Manieren van doen, Kok, Kampen.

Dingemans, G.D.J., 1996b, 'Preken in een postmoderne context. Wat heeft een predikant te zeggen als systemen wegvallen?' in M. Nel (red.), Prediking en Kommunikasie in konteks. "n Huldigingsbundel vir H.J.C. Pieterse, pp. 117-134, Makro Boeke, Voortrekkerhoogte.

Dreyer, J.S., 1998, 'The researcher and the researched: Methodological challenges for practical theology', Praktiese Teologie in Suid-Afrika 13(1), 14-27.

Firet, J., 1968, Het agogisch moment in het pastoraal optreden, Kok, Kampen.

Firet, J., 1987, Spreken als een leerling: praktisch-teologische opstellen, Kok, Kampen.

Gregersen, N.H. \& Van Huyssteen, J.W., 1998, Rethinking theology and science. Six models for the current dialogue, Eerdmans, Grand Rapids.

Hamman, J.J., 2005, When steeples cry: Leading congregations through loss and change, The Pilgrim Press, Cleveland.

Heitink, G., 1984, Pastoraat als hulpverlening: Inleiding in de pastorale theologie en psychologie, 3de druk, Kok, Kampen.

Heitink, G., 1993, Praktische theologie: Geschiedenis, theorie, handelingsvelden, Kok, Kampen.

Hendriks, H.J., 1994, 'Missionêre gemeentebou', Praktiese Teologie in Suid-Afrika 9(2), 180-191.

Heyns, L.M. \& Pieterse, H.J.C., 1990, Eerste treë in die praktiese teologie, Gnosis, Pretoria.

Jonker, W.D., 1977, Die liefde van Christus dring ons, NG Kerkboekhandel, Pretoria.

Kinghorn, J. (red.), 1986, Die NG Kerk en Apartheid, Macmillan South Africa, Johannesburg. 
Kok, J. \& Niemandt, C.J.P., 2009, '(Re)discovering a missional-incarnational ethos', HTS Teologiese Studies/Theological Studies 65(1), Art. \#274, 7 pages. http://dx.doi. Teologiese Studies/Theologica
org/10.4102/hts.v65i1.274

Kritzinger, J.J., 2000, Navorsing in die fakulteit teologie, Universiteit van Pretoria, Pretoria.

Kübler-Ross, E., 1969, On death and dying, 8th reprint, Tavistock Publications Limited London.

Lee, N.C. \& Mandolfo, C. (eds), 2008, Lamentations in ancient and contemporary cultural contexts, Number 43, Society of Biblical Literature, Atlanta.

Linafelt, T., 2008, 'Surviving Lamentations (one more time)', in N.C. Lee \& C. Mandolfo (eds.), Lamentations in ancient and contemporary cultural contexts, n.p., Society of Biblical Literature, Atlanta.

Louw, D.J., 1985, Sin in lyding: 'n Teologiese besinning rondom kruis en opstanding Lux Verbi.BM, Kaapstad.

Louw, D.J., 1999, Pastoraat as vertolking en ontmoeting, Lux Verbi.BM, Kaapstad.

Mason, J., 1996, Qualitative researching, SAGE Publications Ltd., London.

Meiring, P.G.J., 1999, Kroniek van die waarheidskommissie: Op reis deur die verlede en die hede na die toekoms van Suid-Afrika, Carpe Diem, Vanderbijlpark.

Moltmann, J., 2000, Experiences in theology: ways and forms of Christian theology, SCM Press, London.

Moses, J.W. \& Knutsen, T.L., 2007, Ways of knowing, Palgrave Macmillan Ltd, Hampshire/New York.

Müller, J.C., 1996, Om tot verhaal te kom: Pastorale gesinsterapie, RGN-Uitgewery, Pretoria.

Müller, J.C., 2005, 'A postfoundationalist, HIV-positive practical theology', Practical Theology in South Africa 20(2), 72-88.

Nel, M., 1991, 'Die wisselwerking tussen teorie/praxis in die praktiese teologie', Praktiese Teologie in Suid-Afrika 6(1), 22-37.

Nel, M., 1994, Gemeentebou, Orion, Halfweghuis.

Nel, M., 2002, 'Missionêre koers van 58 gemeentes in Suid-Afrika - 'n empiriese verslag', Praktiese Teologie in Suid-Afrika 17(1), 53-75.

Nel, A., 2003, Op soek na God ... buite die kerk? Lux Verbi.BM, Wellington.

Nel, M., 2006, Stories van hoop: Gemeentes wat in hulle konteks 'n verskil maak en hoop bring, CUM, Vereeniging.
Oates, W.E., 1997, Grief, transition and loss, Fortress Press, Minneapolis.

Odendal, F.F. \& Gouws, R.H. (reds.), 2009, Handwoordeboek van die Afrikaanse Taal (HAT), Perskor, Kaapstad.

Osmer, R.R., 2008, Practical Theology. An introduction, Eerdmans, Grand Rapids.

Osmer, R.R. \& Schweitzer, F.L., 2003, Developing a public faith: New directions in practical theology, Chalice Press, St Louis.

Parkes, C.M., 1986, Bereavement: Studies of grief in adult life, 2nd edn., Tavistock, London.

Parkes, C.M., 2006, Love and loss: The roots of grief and its complications, Routledge, London, New York.

Payne, S., Horn, S. \& Relf, M., 1999, Loss and bereavement, Open University Press, Buckingham.

Pieterse, H.J.C., 1991, 'Die wetenskapsteoretiese grondslag van die praktiese teologie', Praktiese Teologie in Suid-Afrika 6(1), 38-51.

Pieterse, H.J.C., 1993, Praktiese teologie as kommunikatiewe handelingsteorie, RGNUitgewers, Pretoria.

Pieterse, H.J.C., 2002, 'Prediking in 'n postmoderne lewensgevoel', Praktiese Teologie in Suid-Afrika 17(1), 75-101.

Puchta, C. \& Potter, J., 2004, Focus group practice, SAGE Publications Ltd, London.

Van Aarde, A.G., 2004, 'Postmoderne epistemologie en postkoloniale hermeneutiek', HTS Teologiese Studies/Theological Studies 60(3), 1105-1125.

Van der Ven, J., 1993, Practical Theology: An empirical approach, Kok Pharos, Kampen.

Van der Ven, J., 1994, 'Empirical methodology in Practical Theology', Praktiese Teologie in Suid-Afrika 9(1), 29-44.

Van Huyssteen, J.W., 1997, Essays in postfoundationalist theology, Eerdmans, Grand Rapids.

Van Huyssteen, J.W., 2006, Alone in the world? Human uniqueness in science and theology, Eerdmans, Grand Rapids.

Van Rensburg, A.P.J., 1979, Die nuwe Afrika, HAUM, Pretoria.

Wester, F. \& Peters, V., 2004, Kwalitatieve analyse: uitgangspunten en procedures, Uitgeverij Coutinho, Bussum.

Worden, J.W., 2003, Grief counseling and grief therapy, Tavistock, London. 